Available Online : http://journals.researchsynergypress.com/index.php/jefltr/index

Journal of English as A Foreign Language Teaching and Research (JEFLTR)

ISSN 2776-4524 (Online) | 2776-4184 (Print)

Volume 1 Number 1 (2021): 37-45

\title{
Students' Satisfaction on Learning TEFL Subject at Fifth Semester English Education Study Program in IAIN Bukittinggi
}

\author{
1Lisa Indria Putri, 2Widya Syafitri \\ 1,2 IAIN Bukitiinggi, Indonesia
}

\begin{abstract}
This study aims to determine student satisfaction in the TEFL learning process. This type of research is a quantitative descriptive study. The total population was 121 students and the research sample was 31 students in the fifth semester of English education at IAIN Bukittinggi and simple random sampling was used as a research sampling technique. Data were collected using a questionnaire. Based on the results of the study, the student satisfaction in implementing TEFL learning on good teaching items showed that students were satisfied (good) with the learning. Based on the results of this study it can be concluded that the fifth semester English students at IAIN Bukittinggi are already satisfied with the TEFL learning.
\end{abstract}

Keywords: Satisfaction, TEFL

This is an open access article under the CC-BY-NC license.

\section{INTRODUCTION}

Teaching English as the foreign language (TEFL) is important for a country to be able to compete with the other countries. TEFL may also refer to a particular methodology for teaching people whose first language is not English. Learning is a process that occurs in almost all learning activities from planning to reporting. The role of students in the learning process is being interactive learners. An active learner is someone who tends to be interested in active experiments and less interested in saving. Active students are students who are physically and mentally active. A good learning system must be able to help students develop themselves optimally and be able to achieve their learning goals.

TEFL is one of obligated course to take in universities for the students who are studying English education study program. TEFL is a compulsory subject that must be mastered by English education students to pass minimum score as one of the requirements to take teaching practice course. This is because TEFL will involve particular discussion related to skills and teaching methods that must be mastered by students such as teaching methods in learning speaking, listening, writing and reading. The skills and teaching methods in TEFL are needed by students because this is the initial foundation to understand and master learning English which will be a provision in the future.

According to Chuah and Ramalu (2011) the process of the learning activities depends on students' satisfaction on that learning. Satisfaction is a cognitive or affective reaction that emerges in response to a single or prolonged set of service encounter. This means that satisfaction is affective and cognitive reaction from the customer towards the service that was given. In this case, satisfaction means the students reaction whether it is affective or cognitive toward the teaching that was given by the teacher is the learning process.

In this case the research was conducted to measure student satisfaction in TEFL learning. Based on preliminary research by using interview with the fifth semester English education study program in IAIN Bukittinggi who learns TEFL. The result of the problem 9,9\% of the 121 students said that they like and feel satisfied when learning TEFL. This is because the existence of TEFL learning can make students more able to understand and understand the learning methods that they must master in learning English, so that when they carry out PPL they already have good Corresponding author :

Lisa Indria Putri lisaindriaputri2796@gmail.com

DOI: $10.31098 /$ jefltr.v1i1.449

Research Synergy Foundation 
Journal of English as A Foreign Language Teaching and Research (JEFLTR)

Vol. 1(1), 37-45

\author{
Students' Satisfaction on Learning TEFL Subject at Fifth Semester English Education Study Program in IAIN \\ Bukittinggi \\ Lisa Indria Putri, Widya Syafitri
}

provisions to apply later. On the other hand, $12,3 \%$ of the 121 students said that they were not satisfied when doing TEFL learning. Their learning process only uses the discussion method, reading papers and ends with a question and answer session. This makes them feel less attractive and less effective in conducting TEFL learning by using discussion and question and answer session at the last meeting. Students want more interesting learning methods such as using media during the learning process and not only using the discussion method. According to ILIESCU (2014) students are attracted to interactive classes that constantly challenge them, making them go beyond their own limits. It means that the students need new version in learning process. The process is good or not the learning that is carried out will have an impact on the final results obtained. Some students said they were not satisfied with the results they got.

Based on the problem above, the researchers wanted to analyze about "how was students' satisfaction on learning TEFL subject at fifth semester English education study program in IAIN Bukittinggi?"

\title{
LITERATURE REVIEW
}

\section{Teaching English as Foreign Language}

According to Petel and Jain (2008) English as Foreign Language (EFL) is the language, especially English, which is used by the people of other country or society. According to Patel and Jain, Foreign Language is the language where the secondary environment is not observed and the people of linguistically foreign societies use such language. According to Mousu and Lurda (2016) most of the world's English teachers are not native speakers of English, and it is not necessary to have a native like command of a language in order to teach it well. Teacher make important role especially professional English teacher in teaching EFL because everything that teacher do in term of teaching and learning process will give affect toward students. Professional teacher is also influence to make teaching EFL successful so that the students can be motivated or unmotivated. Interesting or uninteresting or even diligent or not diligent. Therefore, professional teachers take a crucial part in teaching and learning process.

\section{TEFL as a Subject}

Foreign language is a language acquired and spoken by a person after the first and second language. The language is not used in daily life of the society where the person lives. For the Minang child whose first language is Minang and who lives in Padang, English is a foreign language. In general, English is not the language that is used in everyday life. According to Rohmah (2013) TEFL as one of the subject in college or university was taught in order the students who are about to become an English teacher understand the art of teaching, students and teachers' role, and authentic materials.

\section{Satisfaction}

According to Chuah and Ramalu (2011) the process of the learning activities depends on students' satisfaction on that learning. Satisfaction is a cognitive or affective reaction that emerges in response to a single or prolonged set of service encounter. This means that satisfaction is affective and cognitive reaction from the customer towards the service that was given. According to Zulfani, Satisfaction is different among individuals. Broadly, an individual has a different level of satisfaction in accordance with the applicable value system. According to Sesmiarni and Ilmi (2018) the higher the assessment of the perceived activity in accordance with the wishes of the individual, 
Journal of English as A Foreign Language Teaching and Research (JEFLTR)

Vol. 1 (1), 37-45

\author{
Students' Satisfaction on Learning TEFL Subject at Fifth Semester English Education Study Program in IAIN \\ Bukittinggi \\ Lisa Indria Putri, Widya Syafitri
}

the higher satisfaction of the activity. It means that satisfaction is an evaluation that describes a person's feelings of pleasure or displeasure in doing activities. According to Roza and Khairani (2019) it could learn through teaching process because someone who neutral even someone who has positive belief would influences them. In this case, satisfaction means the students reaction whether it is affective or cognitive toward the teaching that was given by the teacher is the learning process. Moreover, according to Guolla in Suarman, satisfaction is an evaluation which takes place at the end of the process of consumer psychology after the use of a product or service. Students' satisfaction on their learning program is considered as a cumulative satisfaction of the entire program of their study. Students are clients who interests and satisfaction need to be prioritized as a dependent variable.

Based on the theories above, students' satisfaction means any reaction or evaluation from students towards the service, which in this case is TEFL learning, whether how the teacher teaches, the evaluation, the learning progress, or task that is given in TEFL.

\title{
4. Review of Related Literature
}

The first study was conducted by Tomo Djudin with the title the Effect of Teaching Method and Lecture Program on Students' Satisfaction Rates and Academic Achievement. This research examined the effect of teaching method and lecture program on student satisfaction rate and academic achievement of physics education department of Education and Teacher Training (FKIP) of Tanjung pura University, Pontianak. The descriptive method with the causal comparative study was employed in this research. The sample was (232) respondents of fifth semester in academic year 2016/2017 which drawn by using un-proportioned stratified random sampling technique. A questionnaire of lecturer academic service satisfaction was administered. Based on data analysis, the findings of this research are: (1) There is a significant difference of student's satisfaction rate with lecturers' academic service $(t=5.455, \mathrm{p}<0.05)$ and academic achievement $(t=4.149, \mathrm{p}<0.05)$ in terms of lecture method and direct instruction model. The students who having received direct instruction show higher on satisfactions rate and academic achievement than who having received lecture method; (2) There is a significant main effect of the lecture program on the rate of student satisfaction $(F=30.346, p<0.05)$ and on students' academic achievement $(F=15.646, p<0.05)$; (3) There is no significant interaction effect of the teaching method and lecture program on student satisfaction rate $(F=0.753, p>0.05)$ and academic achievement $(F=0.326, p>0.05)$. It recommends that an institution should undertake internal survey to explore student satisfaction with academic services periodically

The second study was conducted by Napitupulu et al with the title Analysis of Student Satisfaction toward Quality of Service Facility. This study aims to determine the extent to which the quality of the services effect on user satisfaction. The research method used is survey-based questionnaire that measure perception and expectation. The results showed a gap between perception and expectations of the respondents have a negative value for each item. This means XYZ service facility at the university is not currently meet the expectations of society members. Three service facility that has the lowest index is based on the perception of respondents is a laboratory (2.56), computer and multimedia (2.63) as well as Wi-Fi network (2.99). The magnitude of the correlation between satisfactions with the quality of service facilities is 0.725 which means a strong and positive relationship. The influence of the quality of service facilities to the satisfaction of the students is 0.525 meaning that the variable quality of the services facility can explain $52.5 \%$ of the variable satisfaction. The study provided recommendations for improvements to enhance the quality of services facility at the XYZ university facilities. 
Journal of English as A Foreign Language Teaching and Research (JEFLTR)

Vol. 1(1), 37-45

Students' Satisfaction on Learning TEFL Subject at Fifth Semester English Education Study Program in IAIN Bukittinggi

Lisa Indria Putri, Widya Syafitri

\section{RESEARCH METHOD}

\section{Research Design}

This research used descriptive quantitative research. Descriptive research is research that describes conditions that already exist. The descriptive research involves gathering, organizing and describing the data. Based on the explanation above, the researcher used descriptive quantitative research. Moreover, the purpose of the research to investigate students' satisfaction on learning TEFL subject at fifth semester English education study program in IAIN Bukittinggi

\section{Participants/Respondents/Population and Sample}

The populations of this research were students in the fifth semester of the English education study program in IAIN Bukittinggi. There were three classes of the fifth semester. The amount of these classes wasone hundred twenty one (121) students. The researcher used simple random sampling for this research. The researcher took $25 \%$ of the fifth semester students of the English Education Study Program at IAIN Bukittinggi, considering the ability of the researcher. As the result, 31 students as a sample in this research and lottery numbers in each class are used in this research.

\section{Instrument}

The instrument defined as a tool that was used to get the data needed by this research. The questionnaire was used in this research as the instrument. A questionnaire designed to investigate the students' satisfaction on learning TEFL. In this research used a closed-ended questionnaire. In this research, the students were asked for a response to the questionnaire. The statement consists of 24 items statements. The questionnaire was used to find what the description of students' satisfaction on learning TEFL was and the questionnaire in form of Indonesian language because to make sure the informant easy to understand the statements. In order to make the instrument becomes valid, the researcher tried out the instrument test. Arikunto stated that the main requirement of the test was valid purposed to measure. Arikunto stated that a questionnaire can be said as a valid questionnaire if it measures what is intended to measure and the instrument was called as a valid instrument when it can give the true description about the data based on reality or fact. There was content validity, construct validity, concurrent validity, and predictive validity. This research used content validity. According to Gay that content validity is determined by expert judgments. Validity was to discover whether a test a measure accurately what was intended to measure or it measure what it was

The questionnaire can be valid if it measures accurately as what was intended to be measured. It means that the research should do the validity to judge the questionnaire was valid by consulting the content validity to the expert: Syahrul, M.Pd, Agseora Ediyen, M.Hum, and Drs. Genta Sakti, Ma were chosen as validator in this research because they were expert about variables of this research.

\section{Technique of the Data Collection}

The crucial thing in doing the research is collecting the data. In collecting the data, the researcher used the questionnaire. Students' satisfaction on learning TEFL subject at fifth semester English education study program in IAIN Bukittinggi. In line with the research design above, the data were taken from the questions that are given by the researcher. In collecting Students' satisfaction on learning TEFL subject result, the researcher gave a questionnaire to students fifth semester English education study program in IAIN Bukittinggi. This questionnaire conducted to make sure that the students' result was originally their satisfaction on learning TEFL subject. Students' to the question are being statically analyzed. 
Journal of English as A Foreign Language Teaching and Research (JEFLTR)

Vol. 1 (1), 37-45

Students' Satisfaction on Learning TEFL Subject at Fifth Semester English Education Study Program in IAIN Bukittinggi

Lisa Indria Putri, Widya Syafitri

\section{Technique for Data Analysis}

The analysis of the data would at the end of the research. This data analyzed by using descriptive statistic which was used to describe a data to a single variable or questionnaire the instrument. The analysis used for answering the research question, it is to find out how is the students' satisfaction on learning TEFL subject at fifth semester English education study program in IAIN Bukittinggi. In this research, the data were analyzed by using these following steps:

a. Analyzing the data

The researcher analyzed the students' answer by using Likert scale. There were five options in answering the questionnaire. Those were always, often, sometimes, rarely and never. The point of always was valued as 5, meanwhile, the point of often was valued as 4, 3 point for sometimes, 2 point for rarely and 1 point for never.

b. The researcher calculated frequency (f) of respondents' answer. The technique of analyzing the data in this research was percentage technique by using the formula $P=f n \times 100 \%$

c. Then measuring Mean of the data by using a formula $\overline{\mathrm{X}}=\Sigma \mathrm{fx} / N$

d. Drawing the conclusion

The researcher calculated all the data percentages got from each indicator to gain the conclusion for each indicator. Furthermore, in order to draw the conclusion, the total of data result was calculated into the table of data interpretation to see the amount of percentages result.

\begin{tabular}{|c|c|}
\hline Mean range & Category \\
\hline $81 \%-100 \%$ & Very good \\
\hline $61 \%-80 \%$ & Good \\
\hline $41 \%-60 \%$ & Good enough \\
\hline $21 \%-40 \%$ & Less \\
\hline $0 \%-20 \%$ & Very less \\
\hline
\end{tabular}

Figure 1. Mean score of satisfaction

\section{FINDINGS and DISCUSSION}

\section{Findings}

\begin{tabular}{|c|c|c|}
\hline Number of categories & Perception of percentage & Rating scale \\
\hline Categories 1 & $76,9 \%$ & Good \\
\hline Categories 2 & $72,2 \%$ & Good \\
\hline Categories 3 & $67,4 \%$ & Good \\
\hline Categories 4 & $62,6 \%$ & Good \\
\hline Categories 5 & $81,2 \%$ & Very Good \\
\hline Categories 6 & $84,5 \%$ & Very Good \\
\hline Categories 7 & $72,2 \%$ & Good \\
\hline
\end{tabular}

41 


\begin{tabular}{|l|l|l|}
\hline Mean & $\mathbf{7 3 . 8 5}$ & Good \\
\hline
\end{tabular}

Figure 2. Students' satisfaction on learning TEFL

a. In categories 1 is good teaching, the good teaching component reflects a good satisfaction in the good teaching component. It reveals means score of good teaching component is 76,9 . In brief, overall statements showed a good satisfaction in learning TEFL

b. In categories 2 is clear outcomes and standard scale, Based on the research, the result of students' satisfaction on learning TEFL in the clear outcomes and standard scale component is good satisfaction. It reveals that mean score of clear outcomes and standard scale component is 72,2 . In brief, overall statements showed a good satisfaction in learning TEFL

c. In categories 3 is appropriate assessment, in this research, it was found that students had good satisfaction related to the appropriate assessment. The finding show that mean score of the appropriate assessment is 67,4. This was clearly seen overall means score of statements appropriate assessment component showed a good satisfaction on learning TEFL.

d. In categories 4 is appropriate workload, in this research, it was found that students had good satisfaction related to the appropriate workload. The finding show that mean score of the appropriate workload is 62,9 . This was clearly seen overall means score of statements appropriate workload component showed a good satisfaction on learning TEFL.

e. In categories 5 is generic skill, in this research, it was found that students had very good satisfaction related to the generic skill. The finding show that mean score of the generic skill is 81,2 . This was clearly seen overall means score of statements generic skill component showed very good satisfaction on learning TEFL.

f. In categories 6 is motivation, in this research, it was found that students had very good satisfaction related to the motivation. The finding show that mean score of the motivation is 84,5 . This was clearly seen overall means score of statements motivation component showed very good satisfaction on learning TEFL.

g. In categories 7 is satisfaction with the module, in this research, it was found that students had good satisfaction related to the satisfaction with the module. The finding show that mean score of the motivation is 72,2 . This was clearly seen overall means score of statements motivation component showed \good satisfaction on learning TEFL. 
Journal of English as A Foreign Language Teaching and Research (JEFLTR)

Vol. 1 (1), 37-45

\author{
Students' Satisfaction on Learning TEFL Subject at Fifth Semester English Education Study Program in IAIN \\ Bukittinggi \\ Lisa Indria Putri, Widya Syafitri
}

In conclusion, the mean of the satisfaction on learning TEFL is $73,85 \%$.. It means that students had a good satisfaction on learning TEFL. the overall results statement regarding the components of good teaching, clear outcomes and standard scale, appropriate assessment appropriate workload, generic skill, motivation, satisfaction with the module, regarding student satisfaction on TEFL learning, good results were found. This is because all components show good satisfaction. These findings reveal that students have satisfaction on learning the TEFL subject.

\title{
2. Discussion
}

Depending on this research, it was found that students were satisfied with the TEFL learning they had done. students feel satisfied because with TEFL learning they can better understand how to teach good English someday, they also feel satisfied with the material and motivation given by the teacher when in the TEFL learning process. In line with Maysa M. Qutob (2018) the research findings revealed that students were very satisfied with the speaking skills, material, and language teachers they acquired. In addition, it was found that a positive correlation was found between the speaking skills acquired by students and the material and with the language teacher.

In more detail, someone's satisfaction has different levels. this is due to the different methods and assessments that apply. As Zulfani Sesmiarni and Darul Ilmi (2018) stated that the broadly, an individual has a different level of satisfaction in accordance with the applicable value system. The higher the assessment of the perceived activity in accordance with the wishes of the individual, the higher satisfaction of the activity. The findings in this study seem similar to the result found in Sik Sumaedi the research results show that students' perceived quality and perceived price have positive influence on the student satisfaction. Besides that, students' perceived quality is more affected to student satisfaction than perceived price.

The satisfaction felt by students thanks to the process they have gone through. Whether or not students are satisfied in a learning process is determined by the process they are undergoing. Students who have a more active attitude in the learning process, at the end of the learning process will feel satisfied with what they have learned. For students who have an inactive or less active attitude in the learning process, at the end of the lesson they will not be satisfied with what they have done. As Leli Lismay and Zubaidah (2019) said, good attitude and motivation play a major role in language learning strategies that lead students to better understand the use of English.

This study support the theory from Calvo and Markaukaite (2014) that said students are satisfied with the quality of their subjects when the learning outcomes and expected standards were clear to them, when the teaching helped them to learn, when they developed valuable graduate attributes, when the assessment allowed them to demonstrate what they have understood, when they could see the relevance of their subject to their degree, when staff was responsive to feedback, when their prior learning prepared them well, when they could understand their teacher, and when the faculty infrastructure was seen to be supportive.

In conclusion, based on this research, student satisfaction with Tefl learning is good. It can be concluded that students are satisfied with the TEFL learning they have done and the results they get at the end of the lesson.

\section{CONCLUSION}

Based on finding discussion that have been presented in the previous chapter, the result showed that students' satisfaction on learning TEFL subject at fifth semester English education 
Journal of English as A Foreign Language Teaching and Research (JEFLTR)

Vol. 1(1), 37-45

Students' Satisfaction on Learning TEFL Subject at Fifth Semester English Education Study Program in IAIN Bukittinggi

Lisa Indria Putri, Widya Syafitri

study program in IAIN Bukittinggi, the students' have a good satisfaction in the learning TEFL which mean score is $73,85 \%$ in good categories. It means that the students feel satisfied with what they have learned and the results they get after learning TEFL. Based on the results of this study. It is suggested that students improve their TEFL learning to make it easier to understand the TEFL material. Suggestions are addressed to students, lecturers and readers. For students, this research can help students to find out how satisfied they are with TEFL learning after they have learned. Besides that, the study was conducted by Suarman with the title Teaching Quality And Students Satisfaction: The Intermediately Role of Relationship Between Lecturers and Students of the Higher Learning Institutes. This study was aimed to identify the intermediately impact of relationship between lecturers and students towards students' satisfaction and lecturers' teaching quality. The study also examined the differences of perceptions on lecturers' teaching quality and students' satisfaction based on gender. This study used a cross-sectional model in determining the relationship between gender and students' satisfaction and their perception on the quality of the lecturers. . The results showed that the relationship between lecturers and students determines the lecturers' teaching quality and students' satisfaction. The findings confirm the role theory of relationship between lecturers and students and the impact of teaching quality in enhancing students' satisfaction as found in various studies conducted abroad, particularly on the constructs being studied. The findings of this study would provide recommendations for trainings or courses to be conducted for the purpose of improving the teaching quality of university lecturers, and helping lecturers to establish better relationship with their students.

\section{LIMITATION \& FURTHER RESEARCH}

The researcher limited the scope of the problems to be researched that students' satisfaction on learning TEFL subject at fifth semester English education study program in IAIN Bukittinggi

\section{REFERENCES}

Calvo, Rafael and Lina Markauskaite. (2014) Factors affecting students' experiences and satisfaction about teaching quality in engineering, South Wales: Unieristy of Sydney

Chuah Francis and Sbramaniam Sri Ramalu (2011) Students Satisfaaction towards the Univiersity, Malaysia: Universiti Utara Malaysia

Gay, L, R. : Competencies for Analyzes and Application

ILIESCU. Adina. (2014) Methods Of Teaching English As A Foreign Language, Appears of The Sibiu Alma Mater University Conference

Lismay, Leli and Zubaidah (2019) strategi pembelajaran Bahasa Inggris Mahasiswa Mahad IAIN Bukittinggi. Jurnal Edukatif: Jurnal Educational Studies

M.F. Patel, Praveen M. Jain (2008) English Language Teaching, (Jaipur: Sunrise Publisher)

Moussu , Lucie \& Enric Lurda, Non-native English-speaking English language teachers: History and research (2016), Canada: Cambridge University Press 
Journal of English as A Foreign Language Teaching and Research (JEFLTR)

Vol. 1 (1), 37-45

Students' Satisfaction on Learning TEFL Subject at Fifth Semester English Education Study Program in IAIN Bukittinggi

Lisa Indria Putri, Widya Syafitri

Qutob, Maysa M. (2018) The Relationship Between EFL Learners' Satisfaction Within the Classroom Environment and Their Speaking Skills. Jurnal English Language Teaching

Rohmah, Zuliati (2013) Teaching English As A Foreign Language, Surabaya: UIN Sunan Ampel

Roza, Veni and Zamratul Khairani (2019) Students' Attitude toward Extensive Reading At English Education Study Program In IAIN Bukittinggi, Faculty of Tarbiyah and Teacher Training, Institut Agama Islam Negeri (IAIN) Bukittinggi

Sesmiarni, Zulfani and Darul Ilmi (2018) Islamic State Institute of Bukittinggi Students' Satisfactionon Academic Atmosphere and Service. Lentera Pendidikan 